\title{
The Impact of Trade Policy Decisions on Social Justice
}

\author{
Sarah C. Goff ${ }^{1}$ \\ Published online: 16 April 2020 \\ (C) The Author(s) 2020
}

\begin{abstract}
Some recent trade decisions, such as the U.S.'s imposition of protectionist measures against China, have attracted fervent popular support as well as outrage. Critics of these trade policies argue that they fail to promote society's own interests. This paper catalogues the different ways that trade decisions can hinder and facilitate a society's pursuit of social justice. I adopt a simple description of trade liberalization: a society forgoes the use of certain policy options (such as tariffs), in order to pursue greater economic productivity through increased trade flows. Using this simple descriptive account, the paper identifies two pathways for a society's trade policies to shape its pursuit of social justice. First, greater economic productivity improves a society's capacities to realize justice, especially distributive justice. I will argue that the value of greater economic capacities depends upon the society's existing capacities and its inclinations to pursue justice. When a society has greater capacities and fails to extend their benefits to its worse-off citizens, these citizens have more serious grounds for complaint. Second, a society forgoes certain policy options when it liberalizes trade, and some of these options may be instrumentally valuable or even necessary for the society's pursuit of justice. I will argue that, under non-ideal conditions, it can be desirable for a society to limit its own policy space so it cannot feasibly select policies that are unjust. Certain protectionist policies have taken on the expressive meaning that some groups are inferior in social and moral status.
\end{abstract}

Keywords Distributive justice $\cdot$ Social justice $\cdot$ Trade justice $\cdot$ Poverty $\cdot$ Inequality

\section{Introduction}

Recent trade decisions have attracted fervent popular support and outrage, such as the U.S.'s imposition of tariffs against China and the U.K.'s plan to exit the E.U.'s Customs Union and Single Market. Critics argue that these policies set back the

Sarah C. Goff

s.goff@1se.ac.uk; scarlsongoff@icloud.com

1 Department of Government, London School of Economics, Houghton Street,

London WC2A 2AE, UK 
interests of the society raising its own barriers to trade. One approach to engaging in the public debate over these policies is to provide information about the economic benefits of trade. According to this approach, citizens support trade protectionism because they tend to be ignorant about the economic benefits of trade liberalization for themselves personally and for society as a whole (Rho and Tomz 2017). However, public opinion research indicates that supporters of trade restrictions tend to express concerns about their own group's declining social status and their perception that trade has a negative impact on society (Mansfield and Mutz 2009; Margalit 2012). To engage with this form of opposition to trade liberalization, it is necessary to assess the overall interests of society and the importance of maintaining particular groups' social status. Contributions to public debate over a society's trade policy should explain what is at stake for the society in its decisions, taking account of both the economic implications and the social implications people care about.

This paper catalogues the different ways that a society's trade policy decisions can hinder and facilitate its pursuit of justice. I do not deny that a society's trade policies can set back non-compatriots' interests. Nor do I deny the ethical importance of these interests. However, public debate over trade policy is largely restricted to concern over society's interests and the claims of domestic groups. ${ }^{1}$ Moreover, much of the literature on the ethics of trade does not take up the question of what a society should do with respect to its unilateral trade policies and its decisions to enter into or withdraw from bilateral and regional trade agreements. ${ }^{2}$ The most extensive philosophical literature on trade is concerned with the global trading system and its governance by the World Trade Organization (WTO). ${ }^{3}$ Some of the aforementioned trade policies are clearly permitted within WTO rules, such as the U.K.'s plan to leave the E.U.'s Single Market and Customs Union. Other trade policies have dubious legality, such as the U.S.'s imposition of tariffs and other restrictions upon Chinese exports. This paper takes up the question of whether a society ought to adopt these policies in the first place, from the perspective of its own pursuit of social justice.

I adopt a simple description of how a society engages in trade liberalization. A society forgoes the use of certain policy options (such as tariffs) in order to pursue greater economic productivity through increased trade flows. This describes a society's decision to enter into a bilateral or regional trade agreement, and it also

\footnotetext{
1 Survey evidence (Ehrlich 2018; Bastiaens and Postnikov 2019) indicates that a minority of the public in the U.S. and in Europe has concern for the impact of trade agreements on labor standards and environmental conditions in foreign countries.

2 Prominent existing views on trade policy from the perspective of social justice include Tesón (2012) and Risse (2007). See James (2012, pp. 203-246), Christensen (2018, pp. 63-90), and Risse and Wollner (2019, pp. 202-231) for discussion of domestic distributional and social issues within their broader arguments about what justice demands with respect to trade. For arguments that a society should adopt trade policies out of concern for the justice and legitimacy of its foreign trading partners, see Barry and Reddy (2008) for a proposal for conditional trade liberalization and Wenar (2015) for a proposal to use economic sanctions.

3 Pogge (2008) argues that the WTO imposes harms on poor countries by denying them the benefits of trade liberalization. By contrast, some political theorists have expressed concern that a weakened multilateral trading system will worsen the prospects for global justice and justice in trade specifically (Moellendorf 2005; Brandi 2014; Risse 2017; Risse and Wollner 2019, pp. 139-156).
} 
describes its unilateral reduction of its own barriers to trade. Using this simple description, this paper will identify two main pathways for a society's trade policies to have an impact on its pursuit of social justice. First, greater economic productivity improves a society's capacities to realize justice, especially distributive justice. I will argue that the value of these greater economic capacities depends upon the society's existing capacities for justice and its inclinations to pursue justice. When a society has greater capacities and fails to extend them for the benefit of its disadvantaged citizens, these citizens have more serious grounds for complaint. Second, a society forgoes certain policy options when it liberalizes trade, and some of these options may be instrumentally valuable or even necessary for the society's pursuit of justice. Under non-ideal conditions, however, I will argue that a society has a reason to limit its own policy space so it cannot feasibly select policies that are unjust. For instance, certain protectionist policies have taken on the expressive meaning that some groups are inferior in social and moral status.

In short, the paper argues that a society has good reason to adopt trade policies that will address the reasons for its own deficiencies of social justice. A society has good reason to refrain from adopting trade policies that exacerbate its failures of social justice. These principles do not produce all-things-considered judgments about whether justice requires a society to liberalize trade or restrict trade. This would require an assessment of the importance of social justice in comparison to global justice, and the importance of social justice (defined independently from trade) in comparison to trade justice. ${ }^{4}$ The paper proceeds as follows. First, I present a simple description of trade liberalization and explain how it differs from other accounts that have been used in normative arguments. Second, I argue that greater economic productivity can help or hinder the pursuit of social justice, with particular attention to distributional issues. Finally, I argue that limiting a society's policy space also may be a help or hindrance to its pursuit of justice, with particular attention to the society's status hierarchy and its expressive meanings.

\section{A Simple Description of a Society's Trade Liberalization}

Here I will explain and defend the paper's use of a simple description of a society's actions to liberalize trade. The description is: a society forgoes the use of certain policy options (such as tariffs) in pursuit of greater economic productivity through increased trade flows. I describe a society as a solitary decision-maker that acts on the basis of assumptions about how other actors will behave. Global trade necessarily involves actors beyond a single society's borders, including foreign individuals, foreign firms, and foreign states. In response to the society's liberalization of trade,

\footnotetext{
4 The former comparison is beyond the scope of this paper's argument. The latter comparison is not needed for its purposes, insofar as there is overlap between trade-independent ideas of social justice and trade justice. In support of the view that these two ideas of justice have considerable overlap, Risse and Wollner write, 'Domestic justice eclipses trade justice to the extent that trade justice concerns domestic matters' (2019, p. 69).
} 
it is assumed that individuals and firms will respond by engaging in more global economic exchanges. Other states are assumed to grant some degree of permission for their own citizens and firms to exchange goods and services across their borders with the society's own citizens and firms. I will argue that my simple description is useful for the purposes of evaluating the impact of a society's trade policy decisions on its pursuit of social justice. To defend my use of the simple description, I contrast it with an account of trade policy as a joint enterprise among societies and an account of trade liberalization as a society's removal of its protectionist laws.

Aaron James' (2012) argument for fairness in trade provides a description of trade as a joint enterprise amongst societies. ${ }^{5}$ James describes trade as a practice of 'mutual market reliance', in which states provide reciprocal assurances. One of the most important assurances they provide one another is that they will refrain from engaging in 'beggar thy neighbor' protectionism. Economists Kyle Bagwell and Robert Staiger have identified certain conditions under which a state could maximize its national income at others' expense through the strategic use of protectionism (Bagwell and Staiger 2002). ${ }^{6}$ Theoretically, a large state could restrict imports in order to alter the global terms of trade in its favor, meaning that the society pays less for its imports and it receives higher prices for its exports. This would increase the society's national income beyond what it would enjoy as a result of reciprocal liberalization with its trading partners. The global trading system allows each society to provide assurance to its trading partners that it will forgo the use of certain policy options (such as tariffs and other trade restrictions) that would increase its own economic benefits at their expense. The society's trading partners reciprocate these assurances by forgoing the use of these same policy options for themselves.

James' description of trade as a practice among states appears to challenge my simple description. James claims it would be 'imprudent' for a society to open its markets without evidence of other societies' firm commitments to mutual gains over the long haul, in case the benefits the society receives from trade are insufficient to offset the various losses that can result from free trade $\left(2012\right.$, p. 59). ${ }^{7}$ Initially, it might appear that endorsing James' definition implies a rejection of my simple description, on the grounds that it is implausibly risky for a state to liberalize trade without assurances from other societies about their responses. However, given that there is a global trading system providing a background framework of rules and mutual assurances, it is not imprudent for a state to make unilateral decisions on the basis of assumptions about how other states are likely to respond. The WTO permits states to unilaterally lower their barriers to trade with developing countries and it permits states to enter into bilateral and regional preferential trade agreements,

\footnotetext{
5 The descriptive account of trade as a joint enterprise, or 'practice', is an essential premise of James' normative argument that countries have claims to fair shares of the gains from global trade.

6 James endorses Bagwell and Staiger's explanation of the origins of the WTO's predecessor, the General Agreement on Tariffs and Trade (GATT), and the current function of the multilateral trading system (2012, pp. 35-75).

7 James notes the potential losses include unfavorable changes in the terms of trade, loss of tariff revenues, adjustment costs (including displacements to workers), and other losses from foreign countries' beggar thy neighbor policies (2012, p. 56).
} 
which leaves states with considerable scope for decision-making about their trade policies.

In addition, there are cases of trade for which it is especially useful to reason about unilateral decision-making. On Bagwell and Staiger's explanation, the GATT/ WTO was formed as a solution to a cooperation problem among large states that each had the capacity to alter the terms of trade in its own favor. Membership in the WTO has since expanded to include small and poor states. However, it remains the case that only large WTO member states can theoretically engage in 'beggar thy neighbor' protectionism. Since poor and small WTO member states do not have the option to alter the terms of trade in their own favor, they cannot provide other states with assurances that they will refrain from making use of an option they do not have. Poor and small states can provide assurances that they will not impose other kinds of losses upon their trading partners. Nevertheless, they participate in the provision of mutual assurances to a more limited extent than rich and large states do with respect to one another. It is especially useful to adopt the simple description of a state's unilateral decisions in cases of trade that involve poor and small states.

Moreover, James' description of trade as a shared practice is not intended to address questions about each state's decisions, in its own particular circumstances, to join or withdraw from trade arrangements. A description of a society's solitary decision-making about trade is necessary to provide James' account with its origin story, specifically, to explain why each society decided to take part in the emerging multilateral trading system. More importantly, James' description is not intended to apply to decisions that concern the possible weakening or dissolution of the multilateral trading system. ${ }^{8}$ If the multilateral trading system significantly weakens or dissolves, it will occur through states' separate decisions to withdraw their support or actively dismantle it. In sum, the simple description of a society's solitary decisions to liberalize trade is useful alongside, and in conjunction with, a definition of trade as a shared practice between states.

Fernando Tesón provides a description of solitary decision-making about trade, and uses this description to argue that free trade policies are required by justice (Tesón 2012; Tesón and Klick 2012). His normative argument for trade liberalization is explicitly premised on the theory of comparative advantage. ${ }^{9}$ On the classical theory of comparative advantage, a country can benefit from trade even when its trading partner produces all goods at a lower cost. Trade allows the country to specialize in the production of goods for which it has lower opportunity costs than the

\footnotetext{
${ }^{8}$ On James' theory of fairness in trade, states' participation in trade is presumed to be legitimate. However, James also argues that global action is needed to achieve structural equity and environmental conservation as a condition for global trade to be permitted to persist: 'So if the cunning of history cannot soften the current resistant state of political will, a move to autarky could well be morally required' (2012, p. 334).

9 Tesón's argument is premised upon either the classical theory of comparative advantage or the Heckscher-Ohlin theory. Both hold that trade liberalization is in a society's economic interests. To complete his case for trade liberalization, Tesón argues that justice requires a society to pursue its economic interests through trade.
} 
other country. ${ }^{10}$ The theory of comparative advantages indicates that it is in a society's economic interests to liberalize trade, whether this liberalization takes place unilaterally or through agreements with other countries.

Tesón defines free trade policies as the opposite of protectionism. A society liberalizes trade by changing its protectionist laws, which Tesón describes as 'artificial, coercive obstacles placed by governments on voluntary transactions across borders' (2012, p. 126). With his co-author Jonathan Klick, Tesón presents two different objections that define the category of protectionist laws. First, 'they coercively redistribute resources in favor of persons who are not deserving beneficiaries under any plausible theory of domestic or international justice. Second, protectionist laws have objectionable consequences because they undermine economic growth and, in so doing, harm persons generally_in particular, the poor' (2012, p. 217). Thus, trade liberalization has two elements. A society liberalizing trade will change its policies that favor domestic producers, by removing the 'artificial obstacles' to international market exchanges. ${ }^{11}$ These changes to protectionist laws will have the effect of increasing the society's economic productivity.

I will make two points against Tesón's description of trade liberalization as the removal of protectionist laws. First, in order to fit Tesón's description of 'artificial, coercive obstacles', protectionist laws must intervene in international market exchanges with an aim to disadvantage foreign producers. But a society can adopt policies that have negative effects on foreign producers and the society's own economic productivity, as side effects of its pursuit of its non-economic interests. These interests could include, for instance, its national security or its interests in safeguarding public health. ${ }^{12}$ It is not protectionist to pursue these non-economic interests, even through trade policies that have the effect of disadvantaging foreign producers and reducing the society's own economic productivity. However, it should count as trade liberalization when the society changes these policies in order to pursue improvements in its economic productivity through increased trade flows.

Second, Tesón describes trade liberalization with reference to a society that makes unilateral changes to its 'protectionist' laws. But this definition does not necessarily apply to a society's decision to liberalize trade by joining a trade agreement with other countries. A trade agreement may require a society to change a specific policy that, on its own, has no discernible impact on trade flows and the society's economic interests. Other states may have written a prohibition on this policy into the terms of the trade agreement for unrelated reasons. ${ }^{13}$ The specific policy itself

\footnotetext{
${ }^{10}$ The other country 'still may import that good if doing so frees up its resources to produce a good in which its trading partner has an even greater cost disadvantage' (Tesón and Klick 2012, p. 225).

11 A tariff is exemplary of a policy that favors domestic producers. A tariff requires consumers to pay a tax on goods from foreign producers, but not domestic producers.

12 Tesón includes 'sanitary rules' and 'national security requirements' on his list of possible forms for protectionist laws $(2012$, p. 126). It will only be clear in a sub-set of cases that these policies aim to benefit domestic producers, rather than aiming to pursue the society's interests in public health and national security.

13 See Rodrik (2018) on the distance between trade theory and the content of contemporary trade agreements, and for his argument that many of these agreements have greater effects on distributional outcomes than on efficiency.
} 
is not 'protectionist'. Nevertheless, it should count as trade liberalization when the society changes this specific policy in order to join a trade agreement that will have the overall effect of increasing trade flows and thereby improving the society's economic productivity.

My simple description of trade liberalization applies to a society's solitary decisions about its barriers to trade and its entry into trade agreements. To liberalize trade, a society forgoes the use of policy options that hinder trade flows or that are forbidden under the terms of a trade agreement. The latter counts as trade liberalization when participating in the trade agreement can be expected to have the overall effect of increasing trade flows and economic productivity for that society. ${ }^{14}$ With this simple description, the paper will proceed to catalogue the effects of a society's trade policy decisions on its pursuit of justice, starting with discussion of the value of increased economic productivity.

\section{Greater Economic Productivity and a Society's Pursuit of Distributive Justice}

Economic productivity refers to a society's production of goods and services (outputs) relative to its use of capital and labor (inputs). This description does not presume a particular standpoint from which to judge greater productivity to be either a source of value or a source of disvalue. ${ }^{15}$ I will evaluate the value of improving a society's economic productivity from the standpoint of its pursuit of justice. Greater economic productivity is valuable primarily when it addresses the economic limitations that hinder a society's pursuit of distributive justice. Greater productivity can exacerbate the society's deficiencies of distributive justice, when a society excludes its worse-off citizens from the benefits of its greater prosperity. For a society deciding whether to liberalize trade, while giving due attention to the decision's implications for its pursuit of justice, I argue that it is important for the society to accurately self-diagnose why it has not yet achieved justice. ${ }^{16}$

I begin by supporting my presumption that a society's trade policy decisions are likely to have some impact on its pursuit of distributive justice. Consider the U.K.'s plan to withdraw from the E.U.'s Single Market and Customs Union. This is a solitary decision that is estimated to have significant and negative effects on the national income. According to recent estimates, the decision will unambiguously

\footnotetext{
${ }^{14}$ My simple description is compatible with the theory of comparative advantage and with increasing returns to scale (Krugman 1991), both of the major explanatory theories of how trade increases a society's economic productivity.

15 What counts as a 'good' or 'service' requires some reference to the idea of satisfying preferences. Nevertheless, an economy can produce more goods at lower cost without necessarily performing better at satisfying preferences. Welfarist theories of distributive justice should take account of trade liberalization's impact on the satisfaction of consumers' preferences through their access to a greater diversity of goods, in addition to taking account of the impact of trade liberalization upon productivity.

16 See Rose (2019) for an argument that a society does not have a duty of justice to pursue economic growth when it already meets requirements for fair distribution.
} 
reduce the U.K.'s rate of economic growth, especially under the scenario of the U.K. leaving the Single Market and Customs Union without a trade agreement in place with the E.U. Furthermore, as a result of leaving the E.U.'s Single Market and Customs Union, consumer prices on food and non-alcoholic drinks are predicted to rise (Dhingra et al. 2017; Clarke, Serwicka, and Winters 2017). These changes will have the greatest impact on the poorest decile of households, because the poorest consumers spend a greater share of their incomes on essentials.

One kind of prediction about this trade policy concerns its impact on the U.K.'s economy as a whole. A second kind of prediction concerns its impact on particular groups within the U.K. Trade economists take pains to distinguish between these two kinds of effects. Trade's overall effects for a society are distinct from its effects on different groups within the society (Dietsch 2017). This distinction is crucial to trade economists' most common defense of trade liberalization. On this defense, societies that are dissatisfied with the distributional consequences of trade liberalization should use the overall benefits from trade to compensate the 'losers', because the benefits to society as a whole will exceed the cost of compensating this group. ${ }^{17}$ This defense aims to provide critics of trade liberalization, who are concerned about its distributional effects for the 'losers', with a decisive reason to endorse trade liberalization. Trade liberalization improves the society's economic capacities to both compensate these losers and to pursue its other goals, including the pursuit of distributive justice that the critics of trade liberalization claim to care about. ${ }^{18}$

In my view, the economists' defense of trade liberalization to the critics who care about distributive justice is not persuasive. Why would it be valuable for a society to have greater capacities for distributive justice, unless the capacities actually will be used for those purposes? ${ }^{19}$ I will now elaborate a more persuasive version of the argument. It is valuable to improve a society's economic capacities when this addresses the reasons that the society has failed to realize justice. To explain the argument, I will make an artificially sharp contrast between a society that is limited only by its capacities and a society limited only by its inclinations. The first society lacks the economic capacities to address absolute poverty, which I assume is one of the essential requirements of distributive justice. ${ }^{20}$ It is valuable to improve this first

\footnotetext{
17 Trade liberalization is Kaldor-Hicks efficient. This means that trade liberalization produces economic gains that could be redistributed in such a way as to make everyone economically better off. However, see Rodrik (2018) for the proposal that contemporary trade agreements mostly produce redistributive outcomes instead of efficiency gains.

18 Economists tend to refer to a trade-independent concept of distributive justice in which trade is merely an instrument for achieving the society's aims. Some critics of trade liberalization may endorse a tradedependent concept of justice. This is a different reason why the economists' response to their critics may fail. Here I am presenting what I take to be the best version of the economists' argument, as a response to those who care about distributive justice as a trade-independent concept.

19 For arguments that the 'losers' from free trade must be provided with actual compensation, see James (2012, pp. 203-221), Christensen (2018, pp. 63-76), and Risse and Wollner's argument that trade without compensation is 'incomplete' (2019, p. 223). The 'losers' are defined as the groups who suffer employment losses and other displacements or who have been made worse off in a more comprehensive sense, specifically as a result of free trade.

20 Absolute poverty can be defined in terms of the means to satisfy basic subsistence needs or other definitions that do not depend upon direct comparisons to the economic condition of other citizens.
} 
society's economic capacities, on the expectation that the society will satisfy duties of justice once it is feasible to do so.

The second society has ample economic capacities and weak inclinations to pursue distributive justice. Imagine this society has a certain expenditure level on its pursuit of distributive justice-including its financial support for food banks-that remains constant over time. Many of the society's members believe it would be inappropriate to provide a greater level of expenditure, on the (false) view that the beneficiaries of public financial support are failing to make use of their opportunities to become self-sufficient. When the society enjoys economic growth in the period following its decision to liberalize trade, a falling share of its capacities will be expended on its pursuit of distributive justice. The society's citizens who use food banks have more serious grounds for complaint that they have been excluded from the benefits of its greater capacities. Improving this society's economic capacities through trade liberalization has exacerbated its deficiencies of justice. In sum, I have articulated a surprisingly negative version of trade economists' defense of free trade. Trade liberalization is a source of disvalue when it increases the gap between what a society can do to satisfy the demands of distributive justice and what the society actually does.

There is no identifiable point when it can be conclusively stated that a society has not and will not make use of its increased economic capacities to pursue distributive justice. There is greater reason to value a society's improvements in productivity when it is more plausible to believe that the society will pursue distributive justice in the future. Consider the argument that a society should provide ex post compensation to workers who have been displaced by trade as a requirement of distributive justice. Since there is a necessary gap in time between a society's decision to liberalize trade and its identification of the displaced workers, it makes sense to value the society's increased economic productivity even when it is not presently being used to provide compensation. By contrast, in the case of the second society described above trade liberalization has the effect of amplifying the claims of groups which are already disadvantaged. ${ }^{21}$ The society's ongoing failure to provide distributive justice for these groups supports a less hopeful assessment of the likelihood that, in the future, the society will use its improved economic productivity for the pursuit of distributive justice. There is still a residual reason to value improvements in the society's economic productivity in this case, because economic productivity tends to persist over time and it is possible that someday the society will change its predominant beliefs about self-sufficiency. ${ }^{22}$

\footnotetext{
21 This contrast is not so sharp when there is overlap between the 'losers' from trade liberalization and already disadvantaged groups. See Christensen's argument that luck egalitarianism requires workers to be compensated for unchosen disadvantages that make them vulnerable to displacement as a result of trade (2018, pp. 68-70).

22 A further question is whether it is valuable for the society to have economic capacities to pursue justice, in cases when its pursuits prove unsuccessful. For instance, a policy to provide food assistance may fail to reach its intended beneficiaries, due to unforeseeable practical problems that could not be addressed by a competent government agency. In my view, it is better from the standpoint of social justice that the society has the economic capacity and inclination to pursue justice, even if its pursuits unavoidably fail in particular cases.
} 
Some argue that the condition of growth makes a positive contribution to a society's inclination to pursue justice. These arguments refer to social scientific evidence that growth has beneficial psychological and social effects on citizens' tendency to take a supportive stance towards social justice. In a growing society, citizens enjoy improvements in their own economic condition. As a result of their personal experiences of greater prosperity, citizens are more inclined to make sacrifices for one another, as well as to trust and tolerate one another (Galston 2014; Friedman 2006). These arguments seem to provide a reason in favor of trade liberalization on the grounds that it improves both a society's economic productivity and its inclination to pursue justice. ${ }^{23}$ However, these arguments identify positive psychological and social effects for societies that already broadly share economic benefits amongst their citizens. This provides a reason for a distributionally equal society to pursue growth, in order to reinforce its citizens' beneficial inclinations towards justice. It also provides a reason for a distributionally unequal society to avoid having its citizens experience stagnation or decline, because this creates a vicious cycle that reinforces citizens' negative inclinations towards justice. However, the argument does not provide a reason for an unequal society to pursue growth when its benefits will not be broadly shared, because there is no evidence this would improve a society's inclination to pursue distributive justice.

In sum, it is important for a society to accurately self-diagnose the reasons why it has not yet achieved distributive justice and whether it is likely to address these reasons in the future. To illustrate how a society might approach this self-diagnosis, consider again the prediction that the poorest groups in the U.K. will suffer from higher food prices as a result of the U.K. leaving the E.U.'s Single Market and Customs Union. The U.K. is a high-income country and it will remain so, even if it suffers some losses to its economic productivity. The U.K. has the economic capacity to fund public expenditures that would fully compensate for higher food prices. However, the reductions in its economic productivity would require the country to use a higher share of its economic capacities for the pursuit of distributive justice. There is reason for doubt that the U.K. will act on a greater inclination to pursue distributive justice for its poorest groups in the future. At this point in time prior to the U.K. leaving the Single Market and Customs Union, the growing strain on the U.K.'s food banks is arguably attributable to the government's austerity policies and its introduction of 'Universal Credit', a unified scheme to provide financial support to the disabled, unemployed, and low-income families (Alston 2019, pp. 8-13).

This section has interpreted a defense of trade liberalization that values improvements in a society's economic productivity. On my development of this argument, however, it is most persuasive for societies whose pursuit of justice is limited primarily by their capacities. It can support the opposite conclusion for societies whose pursuit of justice is limited primarily by their inclinations. If a society does not alter its inclinations to pursue justice, trade liberalization that improves its economic productivity will result in more 'wasted' capacities for the society to realize justice. But

\footnotetext{
23 See Gilabert (2009) on 'dynamic duties' over time to put in place the conditions under which rightsclaims can be feasibly satisfied.
} 
it is also true that this same society, if it becomes less economically productive as a result of raising its barriers to trade, will avoidably do worse at meeting certain non-comparative claims of distributive justice. At the very least, the society requires self-knowledge about whether its pursuit of justice is limited more by its economic capacities or its own inclinations, and whether the society is likely to change those inclinations in the future.

\section{Social Hierarchy and the Expressive Meaning of Policy Choices}

This paper describes two pathways for a society's trade policies to contribute to its pursuit of justice, starting with greater economic productivity. Here I catalogue the effects from the other pathway. To liberalize trade, a society refrains from the use of policy options that are expected to hinder trade flows and thereby reduce its economic productivity. For a society pursuing social justice, it could be useful or even mandatory for the society to adopt a particular policy that happens to disadvantage foreign producers and/or violate the provisions of a trade agreement. It seems that a society's trade decisions pose a straightforward conflict between its pursuit of greater economic productivity and its discretion to adopt particular policies required by social justice. This section will elaborate on this argument and introduce complications that arise for a society which is not yet fully just. Under non-ideal conditions, it can be desirable for a society to limit its own policy space in a trade agreement, so it cannot feasibly select policies that exacerbate its own injustices.

I begin by supporting my presumption that trade decisions have another pathway, apart from considerations of economic productivity, for contributing to a society's pursuit of social justice. Consider the U.S.'s tariffs and other trade restrictions on Chinese exports, which have been imposed in stages since the beginning of Donald Trump's presidency. Several justifications have been offered in support of these trade policies. For instance, it has been argued that President Trump's restrictions on steel and aluminium imports from 2018 to 2019 were necessary to protect U.S. national security interests. If social justice requires national security, then trade restrictions could be necessary for the society's pursuit of justice, even at significant cost to the society's economic productivity. While the argument does not plausibly apply to the U.S.'s restrictions on steel and aluminium imports, it could apply in other cases. ${ }^{24}$ This argument describes a straightforward conflict between a society's pursuit of greater economic productivity and its adoption of policies required by justice. A different argument in favor of tariffs on Chinese exports is that they protect 'good jobs' for U.S. workers in manufacturing industries. I will elaborate on this latter argument.

Before doing so, I will raise a preliminary objection. On this objection, it is simply wishful thinking that restricting trade could maintain access to good jobs. Jobs

\footnotetext{
${ }^{24}$ The argument is that national security interests require the U.S. to maintain some level of domestic capacity to produce steel and aluminium. This is widely considered an unpersuasive attempt to use the GATT/WTO's national security exemption.
} 
exist in a market economy because human labor supports processes of production and exchange. A protectionist trade policy will undermine the society's economic productivity, and thus reduce the availability of jobs. If a society wishes to increase the availability of jobs, it should liberalize trade rather than restricting it. However, this objection does not apply if the argument favors restricting trade in order to maintain the availability of 'good jobs', rather than jobs as such. I will provide a full elaboration of the features of a good job shortly. One feature of a good job is its wage level. Many societies (both rich and poor) have experienced growing wage inequality in recent years, as a result of trade liberalization (Harrison, McLaren, and McMillan 2011). ${ }^{25}$ As a result of trade liberalization, fewer jobs provide the average (median) wage in a society and more jobs provide either much higher wages or much lower wages. If a good job provides the average wage (or higher) in a society, trade liberalization may threaten the availability of good jobs even as it increases the availability of jobs in general.

Now I can state the general form of the argument. A society has a good reason to restrict trade in order to maintain the availability of good jobs, because this is a requirement of social justice that can take priority over the society's prosperity. I will elaborate two versions of the argument, with each referring to a different definition of a 'good job'. A good job could have a single defining feature, namely, that it provides an average wage (or higher). Consider again the aforementioned research on wage inequality, with attention to its implications for workers who had once received average wages. Some of these workers are much better off as a result of trade liberalization, because they have very high wages rather than average wages. Another group is much worse off, because they have low wages rather than average wages. ${ }^{26}$ In the U.S., for instance, there have been estimated job losses in local labor markets for import-competing manufacturing industries as a result of the 'shock' of China's entry into the WTO (Autor, Dorn, and Hanson 2013). If trade restrictions could maintain this group's access to jobs with average wages, this would help the society to fulfill some of the requirements of distributive justice.

This argument articulates an idea of distributive justice that endorses a flatter gradient of economic inequality across the groups of the worst off, the groups in the middle of the distribution (including both the 'working class' and the 'middle class'), and the elites. Specifically, it endorses a flatter gradient of inequality by increasing the share of the population in the middle of the distribution (Schemmel 2011). It is not distributional egalitarianism in the sense of aiming to ensure that everyone has the same economic resources. It is not a theory of distributive justice with absolute priority or a high degree of relative priority for the worst-off groups. Indeed, when this idea of distributive justice is used to support trade restrictions, it can be criticized on the grounds that it is insensitive to the economic condition of the worst off. Trade liberalization would benefit groups without earned incomes because it lowers the cost of living, and it would benefit the unemployed because it increases the quantity of jobs.

\footnotetext{
25 This is separate from the effect on the labor market from technological change.

26 On the idea of harm to these workers from trade, see Loriaux (2018).
} 
One powerful objection to this version of the argument is that trade restrictions are an expensive mechanism to satisfy this idea of distributive justice. It is estimated that every job in U.S. manufacturing saved through trade restrictions has cost over a hundred thousand dollars in forgone economic benefits (Perry 2017). Furthermore, trade restrictions have their own negative effects on the economic condition of groups in the middle of the economic distribution, because these groups are both workers and consumers. Trade liberalization lowers the cost of living through cheaper and better imports. Finally, there are less expensive mechanisms for a society to provide access to jobs that pay average wages. Economists typically recommend that societies should have domestic social insurance and employment programs to provide retraining and other assistance to displaced workers, in order to compensate for the effects of trade liberalization. In sum, even if it is plausible that justice requires concern for the gradient of economic inequalities, trade restrictions are not well supported as a mechanism for satisfying this particular demand of distributive justice.

Now I will elaborate another version of the argument, using a different definition of a good job. A good job is a job that provides its occupant with an average wage and the social status of a 'normal' member of society. ${ }^{27} \mathrm{~A}$ society has a reason to maintain the availability of average-waged jobs, even at significant economic expense, because these jobs provide their occupants with a social status as well as economic benefits. Individuals, groups, and organizations provide many forms of favorable social treatment to the occupants of good jobs. For instance, in many societies, a person with a good job enjoys favorable treatment as a 'normally' suitable candidate as a romantic partner, particularly for marriage. The expressive meaning of beneficial treatment, in this form as well as others, tends to concern the job occupant's moral status. Often the meaning is that the occupant has dignity and moral worth, and her contributions to her society are recognized (Jütten 2017; Sayer 2016). When a worker loses a job with an average wage, she has lost income and the security of her status position as a normal member of society. ${ }^{28}$ In societies that express negative valuations of the occupants of lower-status positions, such as contempt, the loss of an average-waged job can be accompanied by a dramatic decline in status.

This version of the argument articulates an idea of social justice that has strong concern for the social condition of groups in the middle of the economic distribution. A society has a reason to restrict trade to maintain the availability of positions of favorable social status, even at considerable expense to the society's overall economic prosperity. Trade restrictions are justified to maintain a more equal distribution of positions within the status hierarchy, specifically by preserving a share of positions associated with the occupation of average-waged jobs. This argument does not appeal to an idea of social egalitarianism that endorses the equal social status of all citizens. The argument does not appeal to an idea of justice that has primary

\footnotetext{
27 The definition of a 'good job' may also include the use of certain skills, which society recognizes as valuable, in order for the occupant to enjoy access to a favorable social status.

28 The effects of income on opportunities for consumption may reduce her status also, if she therefore lacks opportunities to participate in normal social activities that confer respect in her society (Ci 2013).
} 
concern for improving the absolute or relative positions of groups occupying the lowest social status. Trade restrictions do not plausibly improve the social condition of lower-status groups, because restrictions cannot increase the availability of average-waged jobs to such an extent that lower-status groups gain opportunities for social ascent. Trade restrictions can only be supported by an idea of justice that strongly favors groups in the middle of a society's distribution of economic resources.

This idea of social justice advances a plausible line of criticism against trade liberalization for societies with steep gradients of social and economic inequalities. ${ }^{29}$ It is especially plausible when a society is unlikely to follow the conventional recommendation to offer domestic social insurance and employment assistance. It is also plausible when these programs do not succeed in helping displaced workers find new jobs that secure a 'normal' social status. However, this idea of social justice also endorses social inequalities between groups in the middle of the economic distribution and groups occupying a low social status. The implication is especially problematic in the context of societies that stigmatize their worst-off groups. Some of the most prominent rhetoric in favor of trade restrictions tends to affirm the moral status of particular groups of workers by making negative comparisons to other groups with lower status.

To illustrate that the argument for trade restriction has both of these elements, consider again the U.S.'s current political discussion about trade policy. The debate over trade in the U.S. has been led largely by President Trump, starting with the campaign leading up to the 2016 election. He advances the criticism that trade liberalization contributes to increasing inequalities between workers and elites, using emotional and morally laden rhetoric: 'Our workers' loyalty was repaid... with total betrayal. Our politicians have aggressively pursued a policy of globalization, moving our jobs, our wealth and our factories to Mexico and overseas. Globalization has made the financial elite, who donate to politicians, very, very wealthy' (Skonieczny 2018 , p. 68). In addition, Trump affirms the status of the middle-class workers and the working classes through a contrast with lower status groups, who are characterized as posing a threat. ${ }^{30}$ In particular, Trump draws sharp 'moral boundaries' between workers who deserve jobs and undocumented immigrants, refugees, and Muslims (Lamont, Park, and Ayala-Hurtado 2017). The meaning of his expressions is understood because they refer to existing conventions in the public culture. For instance, expressed support for trade protectionism in the U.S. is stronger when people are exposed to images of white workers, as opposed to black workers, in portrayals of the beneficiaries (Guisinger 2017, pp. 140-173).

There is not necessarily any logical connection between policies that restrict trade and the expression that certain groups are inferior. There is a conventional social meaning of trade protectionism in the U.S., which affirms the social and moral status

\footnotetext{
${ }^{29}$ Many societies have increasingly steep gradients of economic and social inequalities (Milanovic 2016). Trade restrictions may help to flatten the gradient of inequality, by increasing the share of positions in the middle and reducing the benefits of occupying the elite position.

${ }^{30}$ On the overlap between threats to status from racial diversity and from globalization, see Mutz (2018).
} 
of particular workers occupying the middle positions of the economic distribution, while it draws a contrast with the inferior status of other groups. ${ }^{31}$ Given that American society has these conventional meanings and a steep gradient of social and economic inequalities, it difficult to determine whether the U.S.'s pursuit of social justice would be best furthered through trade liberalization or restrictions. In the future, social movements and new political leadership could act to sever the connection between trade protectionism and these social meanings. There could be broader action in the U.S. to undermine its social meanings of contempt and to flatten its social hierarchy, through efforts to broaden access to 'good jobs' and to sever the connection between an average-waged job and its occupant's social and moral status. To make decisions about its trade policy, the U.S. requires a self-diagnosis of whether its most significant problem of non-distributive social justice is its steep gradient of economic and social inequalities or its expressions about the inferiority of other groups, and whether it will address either of these problems in the future.

This paper aims to describe how a society can pursue social justice through its trade policy decisions, while setting aside questions of global justice. However, the arguments for trade protectionism in the U.S. support a greater share of economic benefits to be directed to American workers, rather than foreigners. ${ }^{32}$ This is supported by the assessment that foreigners, particularly the Chinese, have engaged in unfair trading practices. It is a challenge to the paper's framing, particularly its discussion of good jobs as a requirement of social justice, if global justice issues are entangled with social justice. A particularly salient trading practice is 'social dumping', in which low standards for production in foreign countries undermine the competitiveness of domestic industries. Mathias Risse considers a society (A) with relatively high social and labor standards, which negotiates a trade agreement with a society (B) with lower standards (2007). Domestic producers in A are faced with 'race to the bottom' competition on the basis of these standards. Firms in B can produce at a lower price as a result of their low standards, and import-competing domestic producers in A suffer losses. Risse argues that there are global claims of unfairness, of society A against society B, as well as domestic claims of unfairness within A for compensation or trade protectionism for the benefit of its import-competing firms.

Social dumping is a partial explanation for why trade liberalization has a tendency to reduce the availability of good jobs, especially in high-income societies. It does not seem to me that justice provides a reason in favor of restricting trade when social dumping is the explanation for why domestic firms are uncompetitive, without also providing a reason in favor of restrictions when foreign firms are simply more costefficient. We can understand a society's decision to liberalize trade through the two different pathways, regardless of the explanation about how it results in fewer good

\footnotetext{
31 On the wrongfulness of discrimination that degrades through the expression of conventional social meanings of disrespect, see Hellman (2008).

32 See Mutz and Kim (2017) on public support for trade protectionism that will make foreigners worse off.
} 
jobs. First, there is the effect on the society's economic productivity. ${ }^{33}$ Second, there is the effect from the society forgoing the use of certain policy options. Following these two different pathways raises a set of questions for the society to answer about itself. Is it likely that the society will use its improvements in economic productivity to pursue distributive justice, both for already-disadvantaged groups and for workers newly displaced by trade? Will maintaining the availability of good jobs in this society flatten its gradient of social and economic inequalities? Is it likely that the society will alter its conventional social meanings, so that its trade policies aiming to protect good jobs do not also express that certain groups have inferior status?

\section{Conclusion}

This paper has catalogued the different ways that trade decisions can hinder and facilitate a society's pursuit of social justice. Through trade liberalization, a society improves its economic productivity. Many societies fail to make full use of their economic capacities for distributive justice, and thus improvements to their economic productivity can increase the gap between their capacity and performance. During economic downturns, however, these societies may perform less well at addressing absolute poverty and meeting other non-comparative claims of distributive justice. Through trade liberalization, a society forgoes the use of certain policy options. Many societies have increasingly steep gradients of economic and social inequalities that could be addressed, at least partially, through policies that are relevant to trade. However, it is through these same policies that some societies also stigmatize and express contempt for their lower-status groups.

In order to select a trade policy that best facilitates its pursuit of social justice, a society requires self-diagnosis about the reasons why it is not yet fully just. When it is plausible to assume a society will act upon a favorable inclination to pursue justice in the future, its choice between trade liberalization and trade protectionism becomes less difficult. The leading example is the conventional recommendation for a society to engage in redistribution after it liberalizes trade. Further instances are represented in proposals for a society to engage in reforms to flatten its social hierarchy and abandon its expressions that some groups are inferior. This paper has provided a fuller catalogue of the ways in which trade can impact a society's pursuit of justice, especially through analysis of scenarios in which a society is unlikely to act upon a greater inclination to pursue distributive justice or justice as it concerns status hierarchy and expressive meanings.

Acknowledgements I am very grateful to two anonymous reviewers for their excellent suggestions. I also received valuable feedback on earlier versions of this paper from a group of political theorists at LSE and from an audience at LSE's International Inequalities Institute.

\footnotetext{
33 This improvement in economic productivity may benefit many domestic groups in society and foreigners also. It matters whether the middle classes share in these benefits with their fellow citizens, according to an idea of distributive justice. What foreigners gain or do not gain from trade does not influence domestic groups' own claims for distributive justice.
} 
Open Access This article is licensed under a Creative Commons Attribution 4.0 International License, which permits use, sharing, adaptation, distribution and reproduction in any medium or format, as long as you give appropriate credit to the original author(s) and the source, provide a link to the Creative Commons licence, and indicate if changes were made. The images or other third party material in this article are included in the article's Creative Commons licence, unless indicated otherwise in a credit line to the material. If material is not included in the article's Creative Commons licence and your intended use is not permitted by statutory regulation or exceeds the permitted use, you will need to obtain permission directly from the copyright holder. To view a copy of this licence, visit http://creativecommons.org/licen ses/by/4.0/.

\section{References}

Alston, Philip. 2019. Visit to the United Kingdom of Great Britain and Northern Ireland: Report of the Special Rapporteur on extreme poverty and human rights.

Autor, David H., David D. Dorn, and Gordon H. Hanson. 2013. The China Syndrome: Local Labor Market Effects of Import Competition in the United States. American Economic Review 103(6): 2121-2168.

Bagwell, Kyle, and Robert Staiger. 2002. The Economics of the World Trading System. Cambridge, MA: MIT Press.

Barry, Christian, and Sanjay G. Reddy. 2008. International Trade and Labor Standards: A Proposal for Linkage. New York: Columbia University Press.

Bastiaens, Ida, and Evgeny Postnikov. 2019. Social Standards in Trade Agreements and Free Trade Preferences: An Empirical Investigation. The Review of International Organizations. https://doi. org/10.1007/s11558-019-09356-y.

Brandi, Clara. 2014. On the Fairness of the Multilateral Trading System. Moral Philosophy and Politics 1: 227-247.

Christensen, James. 2018. Trade Justice. Oxford: Oxford University Press.

Ci, Jiwei. 2013. Agency and Other Stakes of Poverty. Journal of Political Philosophy 21(2): 125-150.

Clarke, Stephen, Iona Serwicka, and L. Alan Winters. 2017. Changing Lanes: The Impact of Different Post-Brexit Trading Policies on the Cost of Living. UK Trade Policy Observatory: 1-38. Available at: https://www.resolutionfoundation.org/app/uploads/2017/10/Changing-Lanes.pdf. Accessed 9 Apr 2020.

Dhingra, Swati, et al. 2017. The Costs and Benefits of Leaving the EU: Trade Effects. Economic Policy 32(92): 651-705.

Dietsch, Peter. 2017. Growing the Pie or Slicing it Differently-On the Need to Disentangle Two Aspects of Trade Agreements. Global Justice: Theory Practice Rhetoric 10: 43-56.

Ehrlich, Sean D. 2018. The Politics of Fair Trade: Moving Beyond Free Trade and Protection. Oxford: Oxford University Press.

Friedman, Benjamin M. 2006. The Moral Consequences of Economic Growth. Society 43 (2): 15-22.

Galston, William A. 2014. The New Challenge to Market Democracies: The Political and Social Costs of Economic Stagnation. Washington: Brookings Institution Press.

Gilabert, Pablo. 2009. The Feasibility of Basic Socioeconomic Human Rights: A Conceptual Exploration. Philosophical Quarterly 59: 659-681.

Guisinger, Alexandra. 2017. American Opinion on Trade: Preferences Without Politics. Oxford: Oxford University Press.

Harrison, Ann, John McLaren, and Margaret McMillan. 2011. Recent Perspectives on Trade and Inequality. Annual Review of Economics 3: 261-289.

Hellman, Deborah. 2008. When is Discrimination Wrong?. Cambridge, MA: Harvard University Press.

James, Aaron. 2012. Fairness in Practice: A Social Contract for a Global Economy. Oxford: Oxford University Press.

Jütten, Timo. 2017. Dignity, Esteem, and Social Contribution: A Recognition-Theoretical View. Journal of Political Philosophy 25: 259-280.

Krugman, Paul. 1991. Increasing Returns and Economic Geography. Journal of Political Economy 99(3): 483-499. 
Lamont, Michele, Bo Yun Park, and Elena Ayala-Hurtado. 2017. Trump's Electoral Speeches and his Appeal to the American White Working Class. British Journal of Sociology 68: 153-180.

Loriaux, Sylvie. 2018. Protectionism and Fair Trade. Archiv für Rechts- und Sozialphilosophie 104(3): 346-361.

Mansfield, Edward D., and Diana C. Mutz. 2009. Support for Free Trade: Self-Interest, Sociotropic Politics, and Out-Group Anxiety. International Organization 63(3): 1-33.

Margalit, Yotam. 2012. Lost in Globalization: International Economic Integration and the Sources of Popular Discontent. International Studies Quarterly 56(3): 484-500.

Milanovic, Branco. 2016. Global Inequality: A New Approach for the Age of Globalization. Cambridge, MA: Harvard University Press.

Moellendorf, Darrel. 2005. The World Trade Organization and Egalitarian Justice. Metaphilosophy 36(1/2): 158-159.

Mutz, Diana C. 2018. Status Threat, Not Economic Hardship, Explains the 2016 Presidential Vote. Proceedings of the National Academy of Sciences of the United States of America 115: E4330-E4339.

Mutz, Diana C., and Eunji Kim. 2017. The Impact of In-group Favoritism on Trade Preferences. International Organization 71: 827-850.

Perry, Mark J. 2017. Yes, protectionism can save some US jobs, but at what cost? Empirical evidence suggests it's very, very expensive. AEIdeas blog. http://www.aei.org/publication/yes-protection ism-can-save-some-us-jobs-but-at-what-cost-empirical-evidence-suggests-its-very-very-expensive/. Accessed 19 Aug 2019.

Pogge, Thomas W. 2008. World Poverty and Human Rights. Cambridge: Polity Press.

Risse, Mathias. 2007. Fairness in Trade I: Obligations from Trading and the Pauper-Labor Argument. Politics, Philosophy \& Economics 6(3): 355-377.

Risse, Mathias. 2017. Multilateralism and Megaregionalism from the Grounds-of-Justice Standpoint. Global Justice: Theory Practice Rhetoric 10(2): 1-23.

Risse, Mathias, and Gabriel Wollner. 2019. On Trade Justice: A Philosophical Plea for a New Global Deal. Oxford: Oxford University Press.

Rho, Sungmin, and Michael Tomz. 2017. Why Don't Trade Preferences Reflect Economic Self-Interest? International Organization 71(S1): S85-S108.

Rodrik, Dani. 2018. What Do Trade Agreements Really Do? Journal of Economic Perspectives 32: 73-90.

Rose, Julie L. 2019. On the Value of Economic Growth. Politics, Philosophy \& Economics. https://doi. org/10.1177/1470594X19889123.

Sayer, Andrew. 2016. Class, Moral Worth and Recognition. Sociology 39(5): 947-963.

Schemmel, Christian. 2011. Why Relational Egalitarians Should Care About Distributions. Social Theory and Practice 37(3): 365-390.

Skonieczny, Amy. 2018. Emotions and Political Narratives: Populism, Trump and Trade. Politics and Governance 6(4): 62-72.

Tesón, Fernando R. 2012. Why Free Trade is Required by Justice. Social Philosophy and Policy 29(1): 126-153.

Tesón, Fernando R., and Jonathan Klick. 2012. Global Justice and Trade. In Global Justice and International Economic Law: Opportunities and Prospects, ed. Chi Carmody, Frank J. Garcia, and John Linarelli, 217-260. Cambridge: Cambridge University Press.

Wenar, Leif. 2015. Blood Oil: Tyrants, Violence, and the Rules that Run the World. Oxford: Oxford University Press.

Publisher's Note Springer Nature remains neutral with regard to jurisdictional claims in published maps and institutional affiliations. 